\title{
An Appraisal on the Church Museums of Addis Ababa as Tourist Attractions
}

\author{
Abraham Kidane Tesfaye \\ Department of Tourism Management, Debre Berhan University, Amhara Region, Ethiopia \\ Email address: \\ abrishkid@gmail.com

\section{To cite this article:} \\ Abraham Kidane Tesfaye. An Appraisal on the Church Museums of Addis Ababa as Tourist Attractions. Applied and Computational \\ Mathematics. Vol. 8, No. 1, 2019, pp. 17-24. doi: 10.11648/j.jwer.20190801.13
}

Received: April 6, 2019; Accepted: May 23, 2019; Published: June 12, 2019

\begin{abstract}
This paper had done as part of a course work called Culture Based Tourism and was also served as a requirement for a Master Degree Program in Tourism and Development in 2012. As a result, all the used data and facts in this article were collected and referred in the same year. The study focused on assessing the church museums as a tourist attraction in Addis Ababa. Out of the thirteen all types of museums of the city, six of them are owned and administered by the Ethiopian Orthodox Church. Museums are one of the tourism attractions where many tourists flock to perceive the culture and history of human predecessors. The research employed both primary and secondary data which were gathered using interview and thorough observation, published and unpublished written materials, respectively. Using these methods, the research has investigated the three church museums which differ from other church museums in terms of collection, number of visitors and history. Thus, the researcher has deliberately selected on the basis of the above criteria i.e. Ta'aka Be'ata Mariam, Genet Tsige Kudis Georgis and Saint Mariam church museums. They were thoroughly studied and findings were drawn. The research revealed that the church museums have had challenges concerning facilities, absence of promotion, handling of heritages, skilled man power and enticing tourists. Besides, the research also identified the opportunities of the church museums. The research concluded that the church museums could avert the challenges and could capitalize on the prospects if all stakeholders be it government, private and NGOs could play their own role in the promotion, conservation and human development for the betterment of the church museums. Similarly, the church and the community could also play their own part for the progress of the museums.
\end{abstract}

Keywords: Museum, Tourism, Church Museum

\section{Introduction}

Ethiopia is located in east Africa. It occupies around 1.14 million square meters of land and some water bodies and is also one of the largest countries in sub Saharan Africa. The country has possessed unique variety of attractions. An Ethiopian Tourism commissioner Yesuf had presented an article entitled with "Some reflection on tourism in the developed countries -the case of Ethiopia" in a Forum at Barcelona, the article describes that Ethiopia has the potential to appeal different interest groups of tourists because of the fact that she is endowed with paleoanthropological, historical, cultural and natural resources [1].

In other word, as a manifestation for Ethiopia's wonderful resources, which are natural and cultural heritages, impressive scenery, suitable climate, rich avifauna and archaeological [paleontological] sites [2]. In addition,
Ethiopia has eight world heritages which are listed by UNESCO. Furthermore, there are parchment books which contain subjects related with religion, history and others. These parchment books were also registered as world heritages [3].

The capital city of Ethiopia houses historical, cultural and natural heritages. Addis Ababa has both manmade and natural attraction. It has embraced favorable environment, different bird specious, parks, museums, monuments, old historical buildings, mosques, churches, religious festivals or celebrations, market places and others. Addis Ababa embraces in it different international organization, more than hundred embassies and consul offices, and home to nearly three million inhabitants.

The city of Addis Ababa is believed to be established in 1896 [4]; most of the cultural and historical heritages are highly interwoven with the erection and development of the 
city. Most of the country's cultural, historical and natural heritages are housed in the museums of Addis Ababa. Comparatively speaking, the number of museums is higher in number in Addis than in any other regions. These city museums have received relatively significant number of tourists every year.

Ambrose and Paine explain that "museums are the treasure-house of the human race." The modern sense of museum was started in Europe in the $17^{\text {th }}$ century. At first the collections of exotic and rare things were collected as private collection, which then turned into the use of public educational institution. In the contemporary world there are great international museum like the Washington's Smithsonian institution to the smallest one-room museum [5].

Consequently, there are different types of museums across the world. According to Ambrose and Paine museums can be classified into five big categories. They can be categorized based on the collection they housed e.g. ethnographic museum; based on who runs the museum e.g. government museum; and based on the area they serve e.g. national museum. Similarly, they are also classified by the audience they serve e.g. general public museum; and another classification is that museum can be categorized by the way they display their collections e.g. open air museum [5].

In Ethiopia the establishment of museum in a modern sense had coincided with the Ethiopian liberation. It is apparent that the inspiration came undeniably from abroad. Thus, in 1944 the first museum-like was opened in Addis Ababa. It had housed precious objects such as robes, ceremonial clothes, household utensils and others [6].

In the year 1957 an archeological museum was opened in an employees' club of National Bank of Ethiopia. In the meantime the mid of 1960's the objects had transferred into the present day national museum, which is situated at Amest Killo, Addis Ababa. Consequently, the Institute of Ethiopian Studies Museum was also officially opened in 1963. The establishment of museums had continued and during the Derg regime many ethnographical museum had established in different provinces of Ethiopia [6]. Surprisingly, Entoto church museum was officially opened during this supposedly anti-religion regime in 1986 [3]. These all endeavors show how the government has given emphasis to establish museums and related institutions.

Even though Ethiopia had no prior knowledge about the concept of museum, the Ethiopian Orthodox Church has had a long tradition in collecting and protecting the very component of museum. Ambrose and Paine articulated that "Without collections there is no museum" [5]. Ethiopian Orthodox Churches have regarded not only places of worship but also depository of the country's precious heritages [3].

The objects which were collected and preserved by the churches for centuries are most of them recently used for museum consumption. In regards of the church museums of Addis, they have accumulated their precious objects since the reign of Menilik II. However, all the museums of Addis Ababa were established under the churches starting from the mid 1980's.

The church museums of Addis Ababa have shared the city's half of the museums. It means that six out of the thirteen already known museums of the city are belong to the Ethiopian Orthodox Church. These are Entoto Saint Mariam Museum, Ta'aka Negest Be'hata Mariam Museum, Saint Georgis Museum, Kidist Selassie Cathedral Museum, Menbere Patriarch Museum, and Gofa Gebriel Museum. For convenience the first three museums will only be dealt in this paper.

Addis Ababa has become the seat of the imperial regime begging from the late $19^{\text {th }}$ century. The initiative to establish Addis Ababa as a capital city had taken by empress Tiytu the wife of Minilik II [7]. Since it has become a capital, the rulers and the nobles had established number of churches. These rulers and other officials were not only sponsor for the construction of the churches [8] but also they provided the churches with different objects. Those objects they handed over to the churches were either made in the form of gifts or donations. Later on, these objects become the very components of the museums.

\section{Literature Review}

\subsection{Tourism and Ethiopia}

Tourism is the fastest increasing economic sector and also one of the leading segments of the service industry. Nowadays, the economic and social importance of tourism has grown significantly [9].

Tourism in Ethiopia has been increasing rapidly. But the revenue she accrues from tourism is not commensurate with her tourism resources. As United Nations World Tourism Organization demonstrated that Ethiopia has received 330,000 tourists, in return the country has obtained $177,000,000$ USD in 2007. In the publication of world economic forum which was published in 2009, Ethiopia had ranked 123 out of 133 competitors in the world. In this position Ethiopia was only ahead of ten countries. However, Kenya our neighboring was ranked 97 in this same measurement. In the case of regional competitive advantage Ethiopia was still placed behind many countries. While Kenya was positioned 18 in Africa, Ethiopia, on the other hand, was ranked 31 out of forty countries of Africa [10].

The global perspective of tourism can be seen in the WTO's temporary report. According to UNWTO world tourism Barometer of 2009 released in 2011, notes that the share of tourist arrivals and tourism receipts are differed among different continents and sub regions of the world. For instance, Europe has taken the largest share in terms of tourist arrivals and tourism receipts 456.9 million and 410.9 million USD respectively. Asia and pacific has also seized the second large share of tourist arrivals; 180.9 million and tourism receipts; 204.4 million USD. The data has stated about other continents and sub regions. Africa, however, has received meager number of tourists; 48.7 million and has earned 29 million USD. The Africa share further dwindles 
when it has seen in the sub region of Sub Saharan Africa. In this case, the number of tourists who arrived in this region counted around 28.2 million while the income was acquired tallied about 19 million USD [11].

In this region there are around 32 countries of which Ethiopia is one of them. This shows clearly that the share of Ethiopia was undoubtedly insignificant, despite the fact that Ethiopia is awarded with diverse attractions including the twelve registered world heritages and twelve world heritage parchment books and three candidate heritages to be listed as world heritages.

\subsection{Museum and Tourism}

The correlation between museum and tourism goes back to their origin in the enlightenment period. During this time both were the privilege of wealth people. Nevertheless, this legacy was never last long, so that museum and tourism became the rights of other social class. While middle class people involved in tourism internationally, consequently hundreds of museums were opened across the world. The tendency to visit museums were also stimulated by the curiosity of visitors to enhance understanding of the culture, ethnic, historical, natural and other world heritages [12].

The same source also asserted that museums are institutions that are established for the collection, preservation, exhibition, and explanation of cultural and natural events. He further elaborated that the museums can be defined in terms of the knowledge they provide such as art, history, religion, geography and natural history [12].

Recently the cultural tourism has increased sharply as oppose to other type of tourism. This happens because of the museums and other cultural assets are able to entice tourists. Herreman suggests that tourism could not exist without culture. One of the main motivators for people to travel is culture [13]. Amongst the institutions museum is the one of which offer cultural tourist products. This is evidence in Britain. Museums have playing an important role in the tourism and are becoming source of attracting many tourists to Britain. In 2009 eight out of ten top attractions in UK were museums and Galleries. In this same year Britain obtained $£ 19.1$ billion from international tourism and $£ 70.8$ billion by domestic tourism [14], it is possible to say since the high number of tourists attracted by museums and Galleries, economic benefits go to museums and Galleries.

\section{Materials and Methods}

The study was employed both primary and secondary sources. The primary data was gathered from the church museum curators, Addis Ababa Tourism Office Officers and tourists. The data was obtained via deep interview with the above three groups of informants. The other instrument was thorough observation which helped the researcher to identify and single out the perceived success and challenges of the museums. On the other hand, secondary documents were consulted and analyzed. The secondary source of data was gathered through document analysis, including books, journals, periodicals and fliers. The analysis of the data was presented in descriptive with few statistical interpretations of the findings. Because of the nature of the data was gathered and the methods was deployed the qualitative data analysis was pertinent in this study.

\section{Results and Discussions}

\subsection{Ta'aka Negest Be'ata Mariam Church Museum}

Be'ata Mariam is one of the oldest churches in Addis Ababa. Since Addis Ababa had established as a capital city there were a considerable number of churches that had been constructed during the imperial regime. Almost all the time the construction of churches had commissioned by the royal families or by officials. The story of Be'hata mariam is associated with one of the $20^{\text {th }}$ century royal family member.

Nigest Zewditu, the daughter of Minilik, initially planned to construct a mausoleum and memorial building for her father. However, the plan had revised and the church was consequently constructed. The construction had begun around 1902 and lasted a decade later. Then, the church inaugurated and the corps of Minilik is placed inside the church. From that time on ward the church has given honorary title that is Ta'aka Negest meaning (kings' hall) [14]. At different times the corps of Etege Taitu from Entoto and Abune Matewos from Sellasie churches had transferred to Be'ata by Zewditu. These prominent individuals' tombs are still there and it entices visitors [8].

As to the location of the church, it is situated east of the Minilik palace, locally in a place called around Arat Killo. It is surrounded to the south by Gebriel church and to the west and north by the Minilik palace.

As to the structure of the church, it is erected in an area of 500 square meters, totally measured 3705 square meters. The church had constructed in the form of crown with four sides. There are four doors, in front of each there are two bronze made lions and there are eight windows. There are also domes in each corner of the church with similar size and form holding crosses on top of them. As any orthodox church the inside part is partitioned into three namely Qene Mahelet, Mekedes and holly of hollies. In addition, the church's underground holds the mausoleum and other objects [8].

As mentioned above, the museum is placed in underground of the historical building of the church. It holds not only the mausoleum but also there are significant numbers of artifacts gathered and donated to the church at different times.

The museum has housed the tombs of emperor Minilik, Etege Taitu, Nigest Zewditu, Abuna Matewos, and princess Thsaye Haileselssie. In addition to these, there are quite number of other artifacts. There are throne of Minilik and Taitu, seat of Minilik that moved with him from place to place, the president of French Charles Degol condolence gift made of bronze, Minilik's praying book made of parchment, Zewditu's praying books including more than 300 books. Besides, there are about 30 spiritual paintings on canvas, 
cestrum and crosses and others [8].

\subsection{Genet Tsige Saint Georgis Church Museum}

Emperor Minilik had been commissioned for the construction of many churches in Ethiopia in general and in Addis Ababa in particular. While Minilik was in Entoto, the churches of Mariam and Raguel were constructed by him. Later on, when the capital shifted from Entoto to Addis Ababa, the churches of Urael and Georgis just to name a few were built too [15]. Further Minilik declared that his officials and supporters had to construct churches in their respective localities [8].

Prior to the construction of the church of Saint Georgis, there was believed to have been a church there four hundred years ago, which is believed to be built by Zera Yaqob. Nevertheless, during the reign of Gragn it is said to have been destroyed [16].

The covenant of Georgis had first put in the residence of certain foreigner's house in 1885. Eventually, Minilik had constructed hatched roof house for the covenant. However, the present day structure of the church has got its form a century ago. The corner stone had laid in 1895 and consequently at the ensuing year the construction had begun. Finally the church had completed in 1916, but minilik was unlucky to see the completion [16].

This church had hosted two coronations in the $20^{\text {th }}$ century. The first to be coroneted was Empress Zewditu in 1917 and Haileselassie was also anointed as Emperor of Ethiopia in 1930 [16].

The church had been suffered during the Italian occupation. An attempt to murder the Italian officers when it was failed, the Italian soldiers not only massacred innocent Ethiopians but also destroyed churches and heritages of the country. One of the victims for this atrocity was the church of Saint Georgis. They put fire on the church, the paintings and other objects were totally damaged but the building has survived until now. There are two possible propositions why they did such violent action on this church. The one might be the fact that the covenant of this church had been participated in the battle of Adwa. The other is that they allegedly accused this church as a gathering place for bandits [16].

The church of Saint Georgis is situated in Peaza. The place exactly the church is located is named after the church Saint Georgis. It is bounded to the south by the Addis Ababa city Administration and to the east across the road bounded by Addis Ababa City Fire and Emergency Prevention and Control Agency.

Saint Georgis church and the bell tower had been constructed at the same time. The later has now functioned officially as a museum since 1990. Both buildings are historical heritages, so they possess the potential to lure the attention of visitors. The museum is inside the compound of the church but it has its own fence within the church. Two important objects are just placed outside the museum, which are the first monument that was carved in memory of Abuna Petros who was a patriot and was mercilessly murdered by the fascist and the bell presented to Minilik from King of
Russia Czar Nicolas [16]. The interior of the museum has housed different historical, spiritual and cultural objects.

The museum of Georgis church has classified into seven sections. Each portion the museum exhibits a certain theme be it spiritual or historical episodes. The interesting part here is that not only the objects discourse stories but also the inside structure and the showcases as well have something to tell. The reason is that the showcases and the interior are deliberately designed to remind the Aksum and Lalibela's architectural styles. Therefore, the curator is not only explaining about the objects but also the stories behind the architectural designs of the interior and the showcases.

The first section exhibits Nigest Zewditu's coronation costume, shoes made of gold and gold crown granted by empress Menen. In addition to these, there are photos which give you an idea about the oldest hatch roofed church of Georgis, the monument of Minilik before it was removed by the Italians, and the old day's contra the present day's meskel celebration, to name just a few. Actually, this section is known by photograph and painting section.

The emperor Haileselassie coronation costume is housed in the second section. Moving to section three we can see inside the showcase that was designed to replicate the Lalibela, is displayed crosses made of gold and silver. There are also crowns, spiritual objects and even the chalice made of gold granted by Haileselassie. In this section there are also pictures and other heritages.

The fourth section displays the historical painting which is painted by Ethiopian in abroad while Ethiopia was under the Italian rules. The painting depicts saint Mary carried an Ethiopian map which is portrayed the image of a human crying on the hands of St. Mary. According to the curator the painting is manifested, when the league of nation did not accept the allegation made by Haileselassie against Italians, it may be done to represent that Ethiopia stretches her grieve to God [16]. The gifts of Menen vestment and crosses, the gifts Zewditu and Ras Gugesa crosses made of copper and other heritages are housed in this section.

The throne of emperor Hailesellasie and empress Menen are housed in section five. Here with other artifacts the ceiling architectural design is copied one of the churches of rock hewn churches of Lalibela, having had fascinating structures. The old painting that portrays the oldest church image and the surrounding is also part of this section.

In section six there are different parchment books. To mention some of the books that includes Degua, Senkesar, and book of Sinodos. The interior design attempted to replicate the palace of Entoto. The other artifacts that are housed here are the crosses made of gold and diamond donated by Menen. The last section is known by the memorial of Adwa. In this part of the museum weapons, swords, attires which were used in the battle of Adwa are displayed here. The painting of Saint Georgis and the photo Minilik while reading the first newspaper named 'Aemero' are also housed. In addition, there is the notable warrior Fetawerari Habtegeorgis' complete attire with all his war medals and weapons. 


\subsection{Saint Mariam Church Museum of Entoto}

As medieval kings did, empereor Minilik shifted his capital many times. He moved from Anchober to Wechecha and then to Entoto [7]. All of them had served as a capital consecutively one after another. While Entoto had served as a capital, the church of Saint Raguel, Kidist Mariam, the Minilik palace and other edifices had been constructed.

Entoto is located around seven kilo meters away from the center of Addis Ababa. It is placed on the top of the city at $3000 \mathrm{~m}$.a.s.l. Entoto is located to the north of Addis Ababa.

Another important event went on at Entoto was that MinilikII and Taitu had coroneted as Emperor and Empress of Ethiopia at Saint Mary church of Entoto in 1889. The church had been renovated various times. Nevertheless, Etege Taitu had demolished the former church and started to construct a new church. Unfortunately, she couldn't able to finish it but her step daughter Zewditu brought the church into completion the present day structure of the church in 1921.

The church has a circular shape. It is obvious that as any Orthodox Christian church the interior has partitioned into three sections. Unlike to the Behata Mariam, Entoto Mariam has only one dome.

The place entoto offers not only the historical churches, buildings and museum but also provides wonderful panorama of the city of Addis Ababa with its fresh air.

The church of Saint Mariam of Entoto has amassed plenty of collections for more than a century. Nevertheless, these collections were not used for museum consumption until 1987. In this year, under the Derg regime, a building for museum was constructed and it has started to display its objects to the public. It seems deliberate that the museum was opened at the centenary anniversary of the church.

The museum is circular in shape and has only one open space in which different artifacts are housed. The Entoto church museum exhibits cultural, religious, historical and art collections [6].

Vestments are attires put on by priests and deacons during the mass service and other church rituals. These are housed in the museum. In such a kind there are also ritual clothes of the Egyptian Bishop of Abuna Matewos and other highest priests of the church hierarchy.

The churches musical instruments are also housed in the museums. Ceremonial staffs like drum and cestrum are displayed. The former has two kinds, the one is used for church services and the other is named negarit used for great events of the country be it announcement of war or decree of proclamation [17]. These are mainly gifts from kings and other dignitaries of the country.

In the museum, umbrellas and parasols are also housed, which have different functions. On occasions' tabernacle, crosses and other spiritual objects participate in festivity; these usually cover with umbrellas as symbol of honor [18]. On the other hand, parasol was mainly used in the state as well as in the church festivals. It is also taken as sign of dignity and respect [19].
Icons of St. Mary are also displayed at the Entoto Musuem. Most of them are gifts from foreign power to minilik who he then granted to the church.

In the museum, there are different types of clothes that were mainly worn by high level political and religious figures of the country on different occasions during the reign of emperor Menelik and his successors. The collection includes clothes worn by emperor Menelik and emperess Taitu, Ethiopian warriors, prominent nobilities, empress Zewditu, Emperor Haile Selassie, shoes of the kings and the queens [17].

There are also objects that are connected with Menilik and the battle of Adwa. The bed of emperor Menilik made of wood and animal skin is too housed in the museum. An accordion presented to Menelik by Germen officials during his coronation as emperor in 1889 is also a beauty of the museum. A well-equipped and colorfully decorated saddle of Menelik's horse, and the shield, the sword, the rifle carried by Menilik during the battle of Adwa are the valuable treasures of the museum [17].

Photographs are also part and parcel of the museum's collections. Here the museum exhibits those black and white photographs, medals and coins, currency notes and other gifts. The photographs include those of emperor Menelik, empress Teitu, Emperor Haile Selassie, the first Ethiopian patriarch Abune Basilios. The Ethiopian currencies from the reign of Menelik to the present day are displayed and also foreign currency named Maria Theresa thaler coins were granted to the church by different individuals, now are the treasures of the museum. There are also some gold medals given by the renowned long-distance runners.

\subsection{Visitors to the Church Museums}

Entoto Mariam and Beata mariam church museums had received 100 and 27971 domestic visitors in 2015, respectively. In return these museums had gained some incomes. While Beata had obtained 200.00 Birr, ${ }^{1}$ Entoto had accrued more than 200 times of Beata's revenue, it was counted 27,093.50 Birr. The trend in foreign tourists to Beata Mariam was four times the number of domestic tourists. The spending of the foreign tourists was also higher than the domestic ones. It was counted 12,000.00 Birr. On the other hand, international tourists to Entoto museum were also higher than the domestic tourist arrivals and expenditure as well. Thus, the museum earned 103,500.00 Birr in the year 2015. This statistics show that the number of domestic visitors were bizarrely less in number and their consequent expenditure, as oppose to this the foreign tourists were high in terms visit to museums as well as spending. From this data one can conclude that the Ethiopian church museums do not promote and marketing the heritages. Thus, the church should concerted effort to promote the museums and should try to work with stakeholders for the realization of the future well known and managed and visited museums.

The data which holds about Georgis Museum was

${ }^{1}$ Birr is a name for Ethiopian currency. 
conducted in 2013/14. It is not necessary to compare with the previous museums so that it will be analyzed alone. While the museum accepted 1,303 domestic visitors, in return the museum accumulated 2606.00 Birr. Surprisingly, here in this museum too the numbers of international tourists were relatively high, tallied 2967 . The museum totally collected $56,340.00$ Birr in the year abovementioned.

\subsection{The Prevailing Circumstances in the Museums}

\subsubsection{Behata Mariyam}

The challenges that every museum encountered may fall into four categories. This paper used these four criterions in order to identify the problems that are prevailed in the church museums. Some problems can be shared by all museums, but there are distinct problems only specific to a certain museum. These criterions are viz., service provision, collection, Documentation, protection and conservation, and exhibition.

In light with the service provision, Behata Mariam museum has been hindered by the following challenges. This problem sometimes seems simple but its repercussion is massive. To mention some of the challenges; there is inadequate bathroom provision, absence of pamphlet that could help the visitor to know about the objects as an extra information source besides the guide, absence of skilled man power, absence of souvenir shop and restaurants, absence of signage that directs tourist where to go. Besides, there is other peculiar problem in this museum is that it is located adjacent to the palace so that photographing and parking car inside the church are forbidden because of security reasons.

In the case of collection of heritages, there is lack of space so that some treasures were not displayed. In addition, the church has also abandoned to collect heritages because of the same reason.

As to see in the light of documentation all objects in the museum have no accurate and full information. Heritages have to be coded for various reasons including to know the exact number of objects housed in the museum protection and conservation are the principal aims of any museum. In this regard, the museum has faced various problems namely objects are prone to be touched with hands, absence of adequate sunlight and air, these are too critical.

As to exhibition, some objects are displayed in the museum having no or partial information. In principle, museum objects should communicate themselves without of the help of guide or curator. It is done by putting a caption against each object. However, it is the reality not only to Entoto museum but also to others.

\subsubsection{Saint Georgis Museum}

In line with service rendering, the museum doesn't have a bathroom close to it. Even the one away from the museum does not provide adequate service because of absence of water. In addition, similar with Behata Mariam museum, there is no souvenir shop inside the church. Furthermore, the museum doesn't publish any brochure to be used as additional or a guideline for tourists or to promote the museum. Another critical problem is that inadequate knowledge of the administrations how important the heritage has possessed by the church. As a result, the immediate workers of the museum haven't got any training that gives them insight how to protect and conserve the heritages.

Similarly, there are also other acute problems in the museum. The museum is small regarding the size of the space, so that there are quite number of objects that are damped in the store. According to Fekadu, the objects in the store are prone to damage [16]. This has been seen in the parameter of collection.

Regarding protection and conservation, in Saint Georgis museum there are some critical problems. As it was aforementioned, the bell tower of the church is become the museum since 1990. The bell still serving for spiritual activity which is obviously located on top, the ground is for the museum. So, the vibration created by the bell ring, it usually shakes the museum objects which may also undoubtedly alter or damage the objects. In addition, the museum objects since they were locked inside the showcases never get fresh air.

The idea to organize an exhibition in the museum, here is also impossible like Behata Mariam because of the same reason i.e. lack of space.

\subsubsection{Entoto Mariam Museum}

The fact that Entoto Museum is located on the periphery of Addis Ababa, the problem it has faced a bit complicate than the others.

In the case of service provision, here the problem goes beyond and includes some infrastructural challenge. There is lack of water and it hampers the provision of good quality of bathroom service to tourists. The unexpected part is that the problem of providing quality bathroom service is shared by those museums abode in the heart of the city.

Lack of space seems to be the common problems of this church museum. Entoto museum similar with Behata and Georgis has lacked space. This can be evident that some objects are either kept in the store or crammed together in a single showcase. This can put predicament for the hermitage collection.

Some critical problems of the museums are associated with the idea of protection and conservation of the heritages. In this regard, Entoto museum faces varies problems lack of enough showcases, there are objects kept on top of one another. This may lead to alteration or complete damage of the precious heritage. The objects how they are displayed is not done in a good manner so that it may also help for the deterioration of the heritages. The presence of shabby curtain distracts the attractiveness of the objects. Another very critical problem is the building been renovated so that the roof starts to Leak rain water 6 the wall starts to crack and percolate humid air to the museum. Unless this solved very urgently, the damage would be unthinkably heavy.

The quest for exhibition, like the other museums, it seems impossible in Entoto Mariam church museum as well because of space. 


\section{Conclusion and Recommendations}

\subsection{Conclusion}

Ethiopia is endowed with many attractions be it cultural, historical, natural, paleoanthropolgical and etc. In addition to these, Ethiopia has registered eight cultural and natural sites and twelve parchment books as world heritages by UNESCO. In the capital city of Ethiopia, there are manmade and natural attractions. Amongst the many attractions, museums are the principal destinations of tourists.

In Addis Ababa there are more than twelve museums. Some of the museums owns by government and institution, while half of the city museums are found under the umbrella of Ethiopian Orthodox church.

These church museums of Addis Ababa have shared meager amount of tourists, though $95 \%$ tourists have come via Bole Airport. In the year 2007 Ethiopia has received more than three hundred thousand tourists, but the museums have only been visited by seventeen thousand international tourists.

The church museums do not have a strategy to promote and attract tourists. As a result, they are short of attracting sizeable number of visitors.

Lack of space and crammed showcases have caused the poor handling of heritages. Besides, some heritages are housed in the stores where the relics are in bad shape because of absence of proper storing and ventilation mechanism. Thus, some heritages are facing an inevitable deterioration and consequent damage.

Absence of trained manpower is incessant problems at the museums. The curators do not acquire proper training on how to manage and handle issues in the museums. Most of the time the curators are not professionals but someone from the clergies take up the assignment of being a curator or a guide in the museums. Thus, this coupled with other problems could inhibit the museum from being a well-organized one.

Proper documentation and labeling of the heritage is problematic in the museums. Unless there is proper and standardized caption on the museum objects, it would be difficult to convey messages. Currently, most objects in the museums are without caption.

\subsection{Recommendations}

Though the museums are belonged to the Ethiopian Orthodox Church, the collections are heritages to all Ethiopians. Thus, the problems that are observed in the museums should not be only the concern of the church but also other stakeholders such as government, NGO's, and private sectors i.e. tour guide and tour operation agencies.

The common problem of the museums is lack of space. The church should consider constructing new exhibition rooms and storing rooms. In fact the church alone cannot materialize it so that the stakeholders should actively involve even take the initiative to do it.

The church should provide training to the museum staffs and the stakeholders especially government and NGO's should offer material and technical and supports to the museums as well.

Even though all the church museums are being under the Ethiopian Orthodox Church, there is no concerted effort among the churches to promote their museums together. In order to transform the museums into a better standard, the museums should be financially strong. So, through intensive promotions but inexpensive ones like social Medias, the museum can be maximized the number of both tourists and then sizeable income would be acquired by the museums.

Since the church the guardian of the heritages, the museums should be in the hands of the church authority, but other technical works should be done by professionals. In addition, there should be clear demarcation between the museums and the churches in terms of authority, finance, and workers. This could help for transparency and also avoided double duty of some of the workers.

The provision of service should be addressed soon because it distracts the attentions of tourists and creates ill feeling among the visitors.

In the museums some collections do not have a caption attached with them. In principle museum objects should communicate with visitors without a guide, it can certainly be materialized by putting caption in front of each object. This should be done by professionals.

On the other hand, the museums need to have a written rule which can direct the museum staffs what to do and don't do. Of course, this should be prepared by professionals. Another important thing is that the museums should have documentation procedures that help to know how many objects are there, if there is theft, lost and this could be also identified easily.

Exhibition is a good means to create awareness about the museums and their collections. Thus, these museums should deem to commence such activity twice a year or more. This may help the museums to increase their domestic tourists.

\section{References}

[1] Yesuf Abdullahi Sukkar (2004) "Some reflection on tourism in the less developed countries-the case of ethiopia"a presentation by, Ethiopian commissioner of tourism, at fourum Barcelona

[2] (2009) "Tourism in Ethiopia and Tour Operators' Profile" Economic and Business Affairs Directorate General, Ministry of Foreign Affairs.

[3] Mengistu Gobeze. (2010a) 'Bealem Kirsenet Yetemezegebu YeItiopia Yeberana Metsaheft ena Mezagebt,' journal of Ethiopian church studies, no. 1, 29-39 (In Amharic)

[4] Shimelis Bonsa Gulema. (2013) City as Nation: Imagining and Practicing Addis Ababa as a Modern and National Space. Northeast African Studies, Volume 13, Number 1, pp. 167-213

[5] Ambrose, T. and Paine, C. (1993) Museum Basics, London; Rutledge.

[6] Temesgen Burka. (2004) 'The role of Museums and Galleries in Ethiopia' MA Thesis; AAU. 
[7] Bahru Zewde. $2^{\text {nd }}$.ed. (1991) 'A History of Modern Ethiopia 1855-1991,' Oxford: James Currey.

[8] Gilalu Mohammed. (2009) 'survey study conducted over the museum of Ta'aka Negest Be'hata Mariam' commissioned by Addis Ababa culture and Tourism Bureau. (In Amharic)

[9] Theobald, W. ed.(2005) Global Tourism, $3^{\text {rd }}$ ed., Amsterdam; Elsevier Butterworth Heinemann

[10] Blanke, J. and Chiesa, T. (2009) 'The Travel and Tourism Competitiveness Report 2009,' Geneva: World Economic Forum.

[11] UNWTO world Tourism Barometer www.unwto.org/facts, statistical annex Advanced release 2011, p. 4-16.

[12] Jafari, Jafar. (Ed.). (2000). Encyclopedia of Tourism. New york: Rutledge.

[13] Herreman, Y. (1998) 'Museums and Tourism; Culture and Consumption' UNESCO

[14] (2010) Museums and Tourism, National Museums Director's Conference
[15] Mersea Hazen. (1999) Yehagnaw Kifle Zemen Mebacha,' Addis Ababa: Addis Ababa University Press.

[16] Fikadu Fente. (2009) 'Survey study conducted on the establishment of St. George Museum and service provision,' commissioned by Addis Ababa Culture and Tourism Bureau (In Amharic)

[17] Megistu Gobezie. (2010b) 'Entoto St. Mary Museum: the oldest Ethiopian Church Museum' journal of Ethiopian church studies, no. 1, 73-83

[18] Ayalew Sisay. (1990 E. C) 'The Ethiopian orthodox church heritages,' Research paper presented on the Symposium Organized by Ethiopian Cultural Heritage Research and Conservation Authority (In Amharic)

[19] Ewostatewos Wolde Aregawi, ed., (1981 E. C) 'Zena Dabra Tsion of Addis Alem', Addis Ababa; Development Infrastructure Organization, Dabra Tsion, Addis Alem (In Amharic)

[20] (2008) 'Entoto ena Yeturist Mesehbocha' commissioned by Addis Ababa Tourism Commission (In Amharic) 